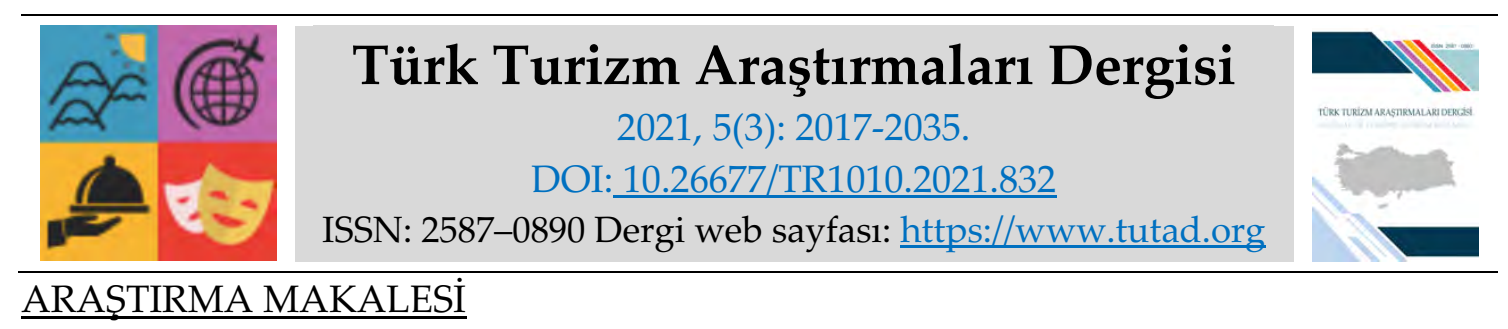

\title{
Pandemi Döneminde Boş Zamanı Değerlendirme Davranışlarının Cinsiyet Değişkenine Göre İncelenmesi
}

Dr. Öğr. Üyesi Ebru Özlem GÜVEN, Çanakkale Onsekiz Mart Üniversitesi, Gelibolu Piri Reis Meslek Yüksekokulu, Çanakkale, e-posta: ebruozlemguven@gmail.com

ORCID: https://orcid.org/0000-0003-1298-8012

Ayşegül ÇAY, Doktora Öğrencisi, Sakarya Uygulamalı Bilimler Üniversitesi, Lisansüstü Eğitim Enstitüsü, Sakarya, e-posta: aysegulcay@outlook.com

ORCID: https://orcid.org/0000-0002-6212-7811

Arş. Gör. Ramazan ÖZAVCI, Balıkesir Üniversitesi, Sağlık Bilimleri Enstitüsü, Balıkesir, e-posta: ramazanozavciii@gmail.com

ORCID: https://orcid.org/0000-0003-3370-8067

Doç. Dr. Abdulmenaf KORKUTATA, Çanakkale Onsekiz Mart Üniversitesi, Spor Bilimleri Fakültesi, Çanakkale, e-posta: akorkutata@comu.edu.tr

ORCID: https://orcid.org/0000-0001-7915-8174

Öz

Araştırmanın amacı, pandemi sürecinde kadın ve erkeklerin boş zamanlarını değerlendirme davranışlarının ortaya çıkarılması ve rekreatif etkinliklere katılım sıklıklarını tespit etmektir. Türkiye evreni içerisinde olasılıklı olmayan örnekleme yöntemlerinden kartopu yöntemiyle belirlenen 628 kişi araştırmanın örneklemini oluşturmuştur. Araştırmada nicel araştırma yöntemlerinden anket tekniği uygulanmıştır. Araştırmanın amacına yönelik 11 hipotez geliştirilmiştir. Araştırma sonuçlarına göre kadınların medeni durum, yaş, eğitim, gelir ve meslek; erkeklerin ise yalnızca yaş değişkenlerine göre boş zamanı değerlendirme davranışları arasında istatistiksel olarak anlamlı bir farklılık olduğu tespit edilmiştir $(p<0,05)$. Kadın ve erkeklerin boş zaman faaliyetlerine katılım sıklıkları arasında da farklılık tespit edilmiştir. Kadın ve erkeklerin boş zaman faaliyetlerine katılım sıklıklarına göre en belirgin fark "müzik dinlerim", "dizi/film izlerim" ve "ailemle zaman geçiririm" faaliyetlerinde ortaya çıkmaktadır. Erkekler açısından ise en belirgin fark "spor müsabakası izlerim" faaliyetinde ortaya çıkmıştır.

Anahtar Kelimeler: Covid-19, Pandemi, Boş Zaman, Rekreasyon.

Makale Gönderme Tarihi: 11.06 .2021

Makale Kabul Tarihi: 05.09.2021

\section{Önerilen Atıf:}

Güven, E. Ö., Çay, A., Özavcı, R. ve Korkutata, A. (2021). Pandemi Döneminde Boş Zamanı Değerlendirme Davranışlarının Cinsiyet Değişkenine Göre İncelenmesi, Türk Turizm Araştırmaları Dergisi, 5(3): 2017-2035.

(C) 2021 Türk Turizm Araştırmaları Dergisi. 


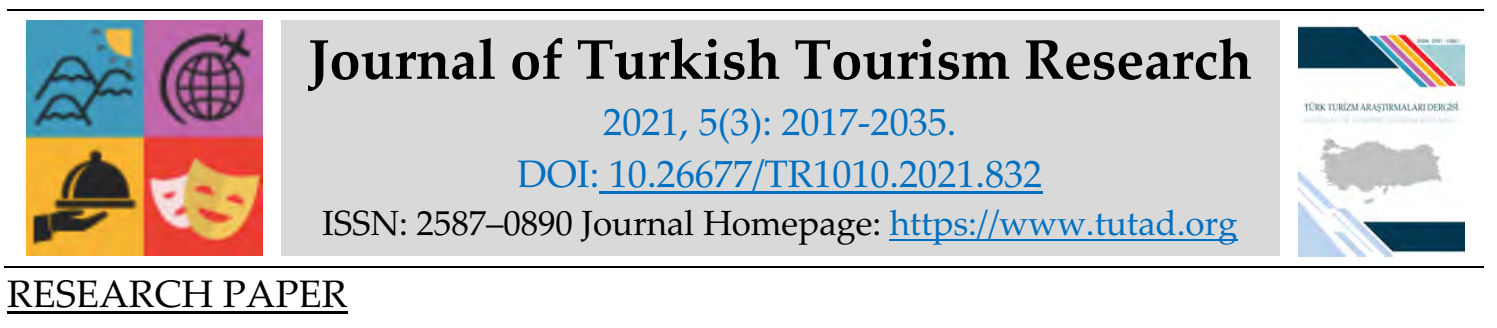

\title{
Investigation According to Gender Variable of Leisure Behaviors During the Pandemic Period
}

Assistant Prof. Dr. Ebru Özlem GÜVEN, Çanakkale Onsekiz Mart University, Gallipoli Piri Reis Vocational School, Çanakkale, e-mail: ebruozlemguven@gmail.com

ORCID: https://orcid.org/0000-0003-1298-8012

Ayşegül ÇAY, Ph.D. Student, Sakarya University of Applied Sciences, Graduate School of Education, Sakarya, e-mail: aysegulcay@outlook.com

ORCID: https://orcid.org/0000-0002-6212-7811

Research Assistant Ramazan ÖZAVCI, Balıkesir University, Health Sciences Institute, Balıkesir, e-mail: ramazanozavciii@gmail.com

ORCID: https://orcid.org/0000-0003-3370-8067

Associate Prof. Dr. Abdulmenaf KORKUTATA, Çanakkale Onsekiz Mart University, Sports Science Faculty, Çanakkale, e-mail: akorkutata@comu.edu.tr

ORCID: https://orcid.org/0000-0001-7915-8174

\begin{abstract}
The aim of the study is to reveal the behavior of men and women to evaluate their leisure time during the pandemic process. In addition, it is to determine the frequency of participation of men and women in recreational activities. In the universe of Turkey determined by the snowball method of non-probability sampling methods the sample of the research consisted of 628 people. The survey technique from quantitative research methods was applied in the research. 11 hypotheses have been developed for the purpose of the research. According to the results of the study, it was determined that there is a statistically significant difference between women's marital status, age, education, income and occupation and men's leisure-time behaviors only according to age variables $(p<0,05)$. Differ was found between the frequency of participation in leisure time activities of women and men. According to the frequency of participation in leisure time activities of women and men, the most significant difference appears in activities "I listen to music", "I watch TV series / movies" and "I spend time with my family". In terms of men, the most significant difference emerged in the activity "I watch sports competition".
\end{abstract}

Keywords: COVID-19, Pandemi, Leisure, Recreation.

Received: 11.06 .2021

Accepted: 05.09.2021

Suggested Citation:

Güven, E. Ö., Çay, A., Özavcı, R. and Korkutata, A. (2021). Investigation According to Gender Variable of Leisure Behaviors During the Pandemic Period, Journal of Turkish Tourism Research, 5(3): 2017-2035.

(C) 2021 Türk Turizm Araştırmaları Dergisi. 


\section{Gíriş}

Dünyada insanlar, MERS, SARS, H1N1, Zika ve Ebola gibi birçok bulaşıı hastalıklar ve etkileriyle karşı karşıya kalmıştır (Yang ve Ma, 2020: 2). 2003 yılında ortaya çıkan şiddetli akut solunum (SARS) hastalığına benzer olarak insanlar arasında hava yoluyla bulaşabilen bir hastalık olan COVID-19, Kasım 2020' de ilk kez Çin'de, devamında dünyanın farklı ülkelerinde ve 11 Mart 2020 tarihinde de Türkiye'de görülmeye başlanmıştır (Budak ve Korkmaz, 2020: 67). İnsanların ölümüne sebebiyet vermesinin haricinde ekonomik, sosyal ve psikolojik olarak pek çok etki de meydana getirmiştir (Mofijur vd., 2020: 37). Hastalığın yayılma hızı ve ölümcül etkisi dikkate alınarak dünya genelinde ve ülkemizde Mart 2020 itibariyle pandemi ilan edilmiştir. Ülkemiz de dahil dünyanın her yerinde sokağa çıkma kısıtlamaları, evden çalışmaya yönelik iş yürütme kararları, yaş aralıklarına göre sokağa çıkma saatleri belirlenmesi, pek çok iş kolunun faaliyetinin kısmi ve tam zamanlı olarak durdurulması, eğitime online olarak devam edilmesi vb. kapanma ve kısıtlama kararları alınmıştır. Bu tür kısıtlamalarla beraber küresel boyutta sosyal yaşam ve ekonomik daralma ile insanların kaygı seviyeleri artmıştır (Cao vd., 2020: 3; Rajkumar, 2020: 2; Mishra vd., 2020:2).

\section{BOŞ ZAMAN ve REKREASYON KAVRAMI}

Zaman, uzun veya kısa, tekrarı olanaksız, başlangıcı ve sonu olan, saatle ölçülen bir kavramdır. Zaman çeşitlerine bakıldığında, biyolojik zaman (yemek, uyumak, vücut temizliği), işgörme zamanı (çalışmak), serbest-boş zaman (oyun, dinlenme, eğlence) olarak ayrılmaktadır (Hacıoğlu vd., 2015: 15). İnsanların zamanları, çalışmak, toplumsal sorumlulukları yerine getirmek, yemekiçmek gibi bölümlere ayrılır. Bu bölümler dışında kalan zamana ise boş zaman adı verilmektedir (Arslan, 2013: 4).

Antik Yunan toplumunda boş zaman, dünyanın gerçek, güzellik, iyilik ve bilgi gibi yüce değerlerinin derin düşünüşü şeklinde tanımlanıyordu. Boş zaman kişinin kendisine zaman ayırması demekti. Bu nedenle Antik Yunan'da boş zaman üst sınıfla ilişkilendirilirken Roma döneminde üretken zamanlardan sonraki zamanları ifade ediyordu (Juniu, 2000: 69). 1960'l1 yıllardan sonra Batılı ülkelerin gelirlerinin artmasıyla insanlar kültür, eğlence, spor, seyahat gibi boş zaman faaliyetlerine dönmüştür. Daha sonra teknolojinin gelişmesi ve endüstriyel ilerlemelerle insan hayatı kolaylaşmış ve buna ek boş zaman doğurmuştur (Aytaç, 2017: 100).

Rekreasyon ise, Latince "recreatio" kelimesinden gelmektedir. Yenilenme ve yeniden yaratılma gibi anlamlar ifade eden rekreasyonun Türkçe karşılığı boş zamanı değerlendirme şeklinde ifade edilebilmektedir (Karaküçük, 2001: 56). Rekreasyon, iyi hissetmek amaçlı gerçekleştirilen her şey olarak da açıklanabilir (Taştan, 2020: 1).

Modern dünyada rekreasyon, boş zamanda bireysel veya grupla gerçekleştirilen eğlendirici, ani tatmin duygusu yaratan ve katılımla birlikte kişilerin yenilenme gereksinimlerini karşılayan faaliyetler olarak ifade edilmektedir (Taştan, 2020: 2). Rekreasyon faaliyetleri, yaş, cinsiyet, kullanılan mekân (açık veya kapalı), zaman (yaz, kış, izin günü vb.) ve faaliyete katılan sayısına (ferdi, grup, aile vb.) göre sınıflandırılabilir (Taştan, 2020: 6). Bunun yanı sıra amaçlarına göre de sınıflandırılabilmektedir (Çakır, 2017: 42). Kişiler, yaşamlarının yaklaşık dörtte birini rekreasyon faaliyetleri ile geçirmektedir (Tütüncü, 2012: 249). Rekreasyon faaliyetleri ev içi, topluluğa dönük, bireysel veya toplumsal olabilmektedir. Bazıları kamu örgütleri vasıtasıyla yapılırken (kilise, cami, belediye vb.) bazıları ise bireysel hobiler ve zevklere yönelik tanımlanabilmektedir. Ayrıca aktif (spor, müzik icra etmek, dans) veya pasif (müzik dinleme, televizyon izleme vb.) boş zaman etkinlikleri olarak da sinıflandırılabilmektedir (Okumuş, 2020: 172; Akt. Aytaç, 2017: 82). 


\section{COVID-19 ve Boş Zaman}

COVID-19 salgını ile küresel çapta ülkelerde sosyal, psikolojik ve ekonomik yönden olumsuz etkiler meydana gelmeye başlamıştır. Giderek daha çok yayılan bu salgının yayılmasını önlemek için ülkeler sosyal izolasyon adı verilen karantina uygulamasına başvurarak insanların evde kalmaları sağlanmıştır (Chen, 2020: 3; Kıvılcım, 2020: 19). Türkiye de sokağa çıkma kısıtlaması uygulayan ülkeler arasında yer almıştır. Ayrıca ülkemizde vaka sayılarında artış olmaya başlamasıyla birlikte kısıtlamalar genişleyerek süreleri arttırılmıştır (www.icisleri.gov.tr). Bu bakımdan insanlar sosyalleşme faaliyetlerini ve boş zamanlarını değerlendirme davranışlarını sürdüremeyecek konuma gelmiştir. Diğer ülkelerde de benzer şekilde insanlar arasındaki teması tamamen ortadan kaldırmak için ve böylece hastalığın yayılımını önlemek için uygulanan kısıtlamalar arttırılmış ve birtakım önlemler alınmıştır (Stodolska, 2020: 2). Bunun yanı sıra barlar, gece kulüpleri, eğlence merkezleri, spor salonları, sanat mekanları, tiyatrolar, sinemalar, müzeler, galeriler gibi pek çok mekân da kapatılmıştır. Spor etkinlikleri de iptal edilmiştir. Seyahat kısıtlamasıyla turizm ise durma noktasına gelmiştir. Bu bakımdan boş zamanın önemi gün yüzüne çıkmıştır (Lashua vd., 2020: 2). Zamanlarının büyük bölümünü evde geçirmek durumunda kalan insanlar, oluşan fazladan boş zamanlarını kısıtlı faaliyetlerle değerlendirme baskısı ile karşı karşıya kalmışlardır. Beraberinde iş sektörünün daralması ile oluşan ekonomik kriz, boş zaman faaliyetlerinin maddi olarak desteklenmesini de kısıtlar duruma getirmiştir. Ayrıca evde kalma zorunluluğu, özellikle toplu konut yaşamı olan apartmanlarda yaşayanlar için, insanların boş zamanlarını değerlendirebilecekleri alanları da kısıtlı hale getirmiştir. Ayrıca spor salonlarının ve aktivitelerinin, eğlence organizasyonları ve mekanlarının, turizm faaliyetleri ve seyahatlerin kapanması ve kısıtlanması gibi faaliyetlerin daralması, pandemi 'de boş zamanlarını kimlerin nasıl değerlendirdiklerine yönelik konuları merak edilen araştırma konusu haline getirmiştir.

Pandemi öncesi ve mevcut süreç içerisinde bireylerin boş zaman davranışları çeşitli araştırmalarca incelenmiştir (Cheval vd., 2020: 8; Mutz ve Gerke (2020: 8). Bireylerin sahip oldukları boş zamanlarda tercih ettikleri rekreatif etkinliklerin onların bilişsel, fiziksel ve davranışsal sağlıkları açısından önemi söz konusu alan yazından da anlaşılmaktadır. Yerli ve yabancı alan yazın incelendiğinde araştırmanın mevcut alan yazına katkı sağlayacağı düşünülmektedir. Bu bağlamda COVID-19 salgın sürecinde kısıtlanan kadın ve erkeklerin boş zamanlarını değerlendirme davranışlarının ortaya çıkarılması ve tercih ettikleri rekreatif etkinliklere katılım sıklıklarını tespit edilmesi bu araştırmanın temel amacı olarak belirlenmiştir.

\section{ARAŞTIRMA METODOLOJISİ}

Araştırma betimsel nitelikte olup, tarama modeli biçimindedir. Tarama modelleri, geniş grupları içeren evrenden seçilmiş bir örneklem grup üzerinde gerçekleştirilen, geçmişte ya da halen var olan bir durumu olduğu haliyle incelemeyi amaçlayan araştırma yaklaşımlarıdır (Karasar, 1994). Nicel araştırma yöntemlerinden, yaygın olarak kullanılması (Douglas ve Connor, 2003: 169; Pizam ve Ellis, 1999: 334) ve elde edilen verilerin kolay analiz edilebilir olması (Altunışık, Çoşkun, Bayraktaroğlu ve Yildirim, 2007) nedeniyle anket tekniği ile veri elde edilmiştir. Anketler kartopu örnekleme yöntemi kullanılarak Google Form üzerinden online yürütülmüştür. Bu araştırmanın Etik Kurul İzni, Sakarya Uygulamalı Bilimler Üniversitesi Etik Kurulu tarafından 03/06/2021 tarihli ve 11 no'lu toplantıda verilmiştir.

Türkiye evreni içerisinde olasılıklı olmayan Örnekleme yöntemlerinden kartopu yöntemiyle belirlenen 628 kişi söz konusu araştırmanın örneklemini oluşturmuştur. Kartopu veya zincir örnekleme tekniği, evreni oluşturan birimlere erişmenin zor olduğu veya evren hakkındaki 
bilgilerin (büyüklük ve bilgi derinliği vb.) eksik olduğu durumlarda kullanılmaktadır (Patton, 2005). Bu teknik, zengin veri elde edilebilecek kişi ve kritik durumlara odaklanmakta ve evrene, bu kişi ve kritik durumları takip ederek ulaşmaktadır (Creswell, 2013). Katılımcıların kişisel bilgilerinin ortaya koyulabilmesi için araştırmacı tarafından bir anket formu hazırlanmıştır. Bu anket formunda katılımcıların cinsiyeti, yaşı, eğitim durumu, gelir durumu ve mesleği tanımlayıcı sorular olarak yer almıştır. Katılımcıların Rekreasyonel faaliyetlere yönelik katılım sıklıklarının ortaya koyulabilmesi için de araştırmacı tarafından ayrı bir anket formu hazırlanıp kullanılmıştır. Anket formunda Rekreasyonel katılım tercihleri için toplam 29 ifadeye yer verilmiştir. Söz konusu rekreasyon tercihleri için "1=Hiçbir Zaman ile 5=Her zaman" 5'li Likert biçiminde cevaplandırılmıştır. Katılımcıların boş zaman değerlendirme durumlarının tespit edilmesi için Akgül (2011)'ün çalışmasından "Boş zaman aktivitelerim sağlığıma katkı sağlar", "Boş zaman aktiviteleri mutluluğumu artırır", "Boş zaman aktivitelerim kişisel gelişimim için bir araç olabilir", "Boş zaman aktivitelerimden hoşlanıyorum", "Boş zaman aktiviteleri için harcadığım zamanın boşa geçmediğini hissediyorum" ifadeleri, Ekinci ve Özdilek (2019)'in çalışmasından "Boş zaman etkinliklerim stres ve kaygımı azaltır" ifadesi olmak üzere bu araştırmaya uygun olan ve araştırmacıların görüşleri doğrultusunda geliştirilen ifadelerle birlikte toplam 14 ifade belirlenip araştırmanın amacına uygun olarak uyarlanmış ve geliştirilmiştir.

Belirlenen ölçüm modelinin kapsam geçerliliği ve görünüş geçerliliği 3 uzman tarafından incelenmiş ve 2 ifade dişarıda bırakılarak söz konusu yapı uygun bulunmuştur. Elde edilen ölçüm modeli için 101 kişilik bir gruba pilot çalışma yapılmıştır. Pilot çalışma sonuçları anlamlı bulunmuştur $(p<0,05)$. Araştırmada hipotezlerin test edilmesi aşamasına geçmeden önce kullanılacak olan ölçüm modelinin güvenilirliği ve geçerliliği test edilmiştir. Ölçüm modelinin güvenilirlik sonuçlarının incelenmesi için Cronbach Alpha ve birleşik güvenilirlik (CR: Composite Reliability) testleri uygulanmıştır. Cronbach Alpha çok sayıda değişken olduğunda yüksek değerler verme eğiliminde olan bir test yöntemi olduğundan birleşik güvenilirlik değeri Cronbach Alpha değerine bir alternatif olarak ya da bir kontrol aracı olarak kullanılabilmektedir (Yaşlığlu, 2017: 82). Birleşik güvenilirlik değerinin 0,60'dan büyük olması beklenir (Hair, Risher, Sarstedt ve Ringle, 2019). Ölçüm modelinin geçerliliğini test etmek amacıyla yapı geçerliliği (construct validity), ayrım geçerliliği (discriminant validity) ve uyum geçerliliği (convergent validity) incelenmiştir (Peter, 1981: 136). Ölçüm modelinin yapı geçerliliği açımlayıcı faktör analiziyle (AFA) incelenmiştir. Ayrım geçerliliği için, ölçüm modelindeki boyutların korelasyon değerlerinin ortalama açıklanan varyansın karekök ( $\mathrm{AVE}$ ) değerinden düşük çıkmış olması ile beklenir (Fornell ve Larcker, 1981). Uyum geçerliliği için, ortalama açıklanan varyans (AVE) değerinin 0,50'den (Hair vd., 2019) büyük olması ve bütünleşik güvenilirlik (CR) değerlerinin 0,60'ın (Bagozzi ve Yi, 1988) üzerinde olması beklenir. Araştırmada kullanılacak analiz testlerine karar verebilmek için veri dağılımları incelenmiştir. Bu bakımdan verilerin çarpıklık ve basıklık değerlerinin \pm 2 aralığında olması beklenmektedir (Brown, 2016). Çıkan sonuçlar bu aralıkta olduğundan parametrik test yöntemlerine başvurulmuştur. Araştırmada test edilmek üzere 11 hipotez kurulmuştur.

Hı: Kadınların medeni durum değişkenine göre boş zamanı değerlendirme davranışları arasında istatistiksel olarak anlamlı bir farklılık vardır.

$\mathbf{H}_{2}$ : Erkeklerin medeni durum değişkenine göre boş zamanı değerlendirme davranışları arasında istatistiksel olarak anlamlı bir farklılık vardır.

$\mathbf{H}_{3}$ : Kadınların yaş değişkenine göre boş zamanı değerlendirme davranışları arasında istatistiksel olarak anlamlı bir farklılık vardır.

$\mathbf{H}_{4}$ : Erkeklerin yaş değiş̧kenine göre boş zamanı değerlendirme davranışları arasında istatistiksel olarak anlamlı bir farklılık vardır. 
H5: Kadınların eğitim değişkenine göre boş zamanı değerlendirme davranışları arasında istatistiksel olarak anlamlı bir farklılık vardır.

H6: Erkeklerin eğitim değişkenine göre boş zamanı değerlendirme davranışları arasında istatistiksel olarak anlamlı bir farklılık vardır.

H7: Kadınların gelir değişkenine göre boş zamanı değerlendirme davranışları arasında istatistiksel olarak anlamlı bir farklılık vardır.

Hs: Erkeklerin gelir değişkenine göre boş zamanı değerlendirme davranışları arasında istatistiksel olarak anlamlı bir farklılık vardır.

H9: Kadınların meslek değişkenine göre boş zamanı değerlendirme davranışları arasında istatistiksel olarak anlamlı bir farklılık vardır.

$\mathbf{H}_{10}$ : Erkeklerin meslek değişkenine göre boş zamanı değerlendirme davranışları arasında istatistiksel olarak anlamlı bir farklılık vardır.

Hı1: Kadın ve erkeklerin boş zaman faaliyetlerine katılım sıklıkları arasında farklılık vardır.

\section{BULGULAR}

Bu bölümde ölçüm modeline ilişkin güvenilirlik ve geçerlilik test sonuçlarının yanı sıra, frekans ve yüzde değerlerinin olduğu tablo ve hipotez test sonuçları yer almaktadır.

\section{Güvenilirlik ve Geçerlilik Sonuçları}

Araştırmada Boş Zamanı Değerlendirme (BZD) ölçüm modeline yönelik güvenilirlik, geçerlilik, ortalama, standart sapma ve korelasyon değerleri Tablo 1 ve Tablo 2'de detaylı olarak verilmektedir.

Tablo 1. Boş Zamanı Değerlendirme Korelasyon Sonuçları ve Tanımlayıcı İstatistikler

\begin{tabular}{|c|c|c|c|c|c|c|}
\hline Boyutlar & $\bar{X}$ & S.S. & 1 & 2 & 3 & 4 \\
\hline Fayda & 3,57 & 0,86 & ,754 & & & \\
\hline Değerlendirme & 3,13 & 1,11 &, $187^{* *}$ & ,800 & & \\
\hline Kalite & 3,68 & 0,82 &, $305^{* *}$ &, $181^{* *}$ & 790 & \\
\hline Maliyet & 3,60 & 1,13 &, $084^{*}$ &, $217^{* *}$ &, $127^{* *}$ & ,888 \\
\hline
\end{tabular}

X: Ortalama:S.: Standart sapma, Koyu yazılar AVE karekök değerleridir ( $\sqrt{ } A V E)$,

${ }^{* *}=p=<0,01 ;{ }^{*}=p<0,05$

Ölçüm modelindeki korelasyon değerlerinin AVE karekök değerlerinden düşük olması nedeniyle söz konusu yapının ayrım geçerliliğinin olduğunu göstermektedir (Fornel ve Larcker, 1981).

BZD 'nin yapı geçerliliğini belirlemek ve söz konusu yapının faktör durumunun ortaya koyulması amacıyla açımlayıcı faktör analizi (AFA) uygulanmıştır. Buna göre, KMO değeri 0,720>0,700, $\mathrm{Ki}^{2}$ değeri 1907,022, df değeri 66 ve $\mathrm{p}=0,000$ şeklinde çıkmıştır. Ayrıca ortak varyans (Communality) değerleri 0,507-0,810 arasında tespit edilmiştir. Açıklanan toplam varyans dört alt boyutlu yapı için \%65,525 olarak bulgulanmıştır. Bu sonuçlar ölçüm modelinin yapı geçerliliğini sağladığını göstermektedir. Ayrıca 4 boyutlu bir yapının meydana geldiğini 
göstermektedir. Uyum geçerliliğini test etmek için ortalama açıklanan varyans (AVE) ve bütünleşik güvenilirlik (CR) değerleri incelenmiştir (Fornell ve Larcker, 1981). Buna göre, AVE değerinin 0,50'nin üzerinde (Hair vd., 2019) olması ve CR değerinin 0,60'ın üzerinde (Bagozzi ve Yi, 1988) olması söz konusu ölçüm modelinin uyum geçerliliğini sağladığını göstermektedir. BZD 'nin içsel tutarlılığ Cronbach Alpha katsayısına göre yorumlanmış ve çıkan sonuçlar 0,70 üzerinde olduğu için ölçüm modelinin güvenilir olduğu kabul edilmiştir. Ayrıca ölçüm modelinin bütünleşik güvenilirliği (Composite Reliability) incelenmiş ve $C R$ değerlerinin 0,60 üzerinde olması nedeniyle içsel tutarlılık doğrulanmıştır (Hair vd., 2019). Böylece ölçüm modelinin güvenilir ve geçerli bir yapıda olduğu kabul edilmiştir.

Tablo 2. Geçerlilik ve Güvenilirlik Analizi Sonuçları

\begin{tabular}{|c|c|c|c|c|c|}
\hline \multirow{2}{*}{\multicolumn{2}{|c|}{$\begin{array}{l}\text { Faktör İfadeleri } \\
\text { Fayda }\end{array}$}} & \multirow{3}{*}{ AFA } & \multicolumn{3}{|c|}{ Testler } \\
\hline & & & CR & AVE & CA \\
\hline 1 & 9.Evde geçirdiğim boş zamanlardan memnunum. & & \multirow{4}{*}{840} & \multirow{4}{*}{, 568} & \multirow{4}{*}{,760 } \\
\hline 2 & 10.Evde boş zaman aktiviteleri gerçekleştirmek sağlığıma iyi gelir. & 0,788 & & & \\
\hline 3 & 11.Evde boş zaman aktiviteleri gerçekleştirmek beni mutlu eder. & 0,812 & & & \\
\hline 4 & 13.Boş zaman aktiviteleri stres ve kaygımı azaltır. & 0,692 & & & \\
\hline \multicolumn{6}{|c|}{ Değerlendirme } \\
\hline 5 & 1.Boş zamanlarımda hiçbir şey yapmak istemem. (T) & 0,710 & \multirow{3}{*}{841} & \multirow{3}{*}{640} & \multirow{3}{*}{,735 } \\
\hline 6 & 3.Boş vaktimi nasıl değerlendireceğimi bilmiyorum. $(\mathrm{T})$ & 0,862 & & & \\
\hline 7 & $\begin{array}{l}\text { 4.Boş vaktimi değerlendirme konusunda yaratıcı fikirler } \\
\text { geliştiremiyorum. }(\mathrm{T})\end{array}$ & 0,821 & & & \\
\hline \multicolumn{6}{|c|}{ Kalite } \\
\hline 8 & 2.Boş zamanlarımda çeşitli aktiviteler yaparım. & 0,752 & \multirow{3}{*}{879} & \multirow{3}{*}{ 625 } & \multirow{3}{*}{,705 } \\
\hline 9 & 5.Boş zamanlarımı verimli geçirdiğimi düşünüyorum. & 0,787 & & & \\
\hline 10 & $\begin{array}{l}\text { 6.Boş zamanlarımdaki yaptığım aktiviteler kişisel gelişimime katkı } \\
\text { sağlar. }\end{array}$ & 0,794 & & & \\
\hline \multicolumn{6}{|c|}{ Ekonomi } \\
\hline 11 & $\begin{array}{l}\text { 7.Yapmak istediğim bazı boş zaman aktiviteleri için maddi koşullar } \\
\text { yüksek olmalıdır. }\end{array}$ & 0,889 & \multirow{2}{*}{,882 } & \multirow{2}{*}{,788 } & \multirow{2}{*}{,765 } \\
\hline 12 & $\begin{array}{l}\text { 8.Kaliteli boş zaman aktivitesi için maddi koşullar yüksek } \\
\text { olmalıdır. }\end{array}$ & 0,887 & & & \\
\hline
\end{tabular}

Araştırmaya katılım sağlayan kadınların $\% 71,7^{\prime}$ si ve erkek katılımcılarında yine $\% 62,3^{\prime}$ ünün bekar olduğu anlaşılmıştır. Katılımcıların yaşları dikkate alındığında \%41,3 ile kadınlarda ve \%33,5 ile erkeklerde 21-31 yaş aralığının olduğu tespit edilmiştir. Kadınların \%44,4'ü ve erkeklerinde $\% 51,8$ 'inin Lise düzeyinde eğitim seviyesine sahip oldukları görülmektedir. Kadın katılımcıların \%38,4'ü ve erkek katılımcıların \%31'inin 1000 TL altında gelire sahip oldukları saptanmıştır. Meslek değişkenine göre yapılan incelemede kadın katılımcıların \%47,9'unun ve erkek katılımcıların \%55'inin özel sektör çalışanı oldukları bulgusuna ulaşılmıştır.

Araştırmaya katılım sağlayan kadınların $\% 71,7^{\prime}$ si ve erkek katılımcılarında yine \%62,3'ünün bekar olduğu anlaşılmıştır. Katılımcıların yaşları dikkate alındığında \%41,3 ile kadınlarda ve $\% 33,5$ ile erkeklerde 21-31 yaş aralığının olduğu tespit edilmiştir. Kadınların \%44,4'ü ve erkeklerinde $\% 51,8$ 'inin Lise düzeyinde eğitim seviyesine sahip oldukları görülmektedir. Kadın katılımcıların \%38,4'ü ve erkek katılımciların \%31'inin 1000 TL altında gelire sahip oldukları saptanmıştır. Meslek değişkenine göre yapılan incelemede kadın katılımcıların \%47,9'unun ve erkek katılımcıların \%55'inin özel sektör çalışanı oldukları bulgusuna ulaşılmıştır. 
Tablo 3. Betimsel Analiz Sonuçları

\begin{tabular}{|c|c|c|c|c|c|c|c|c|c|}
\hline \multicolumn{3}{|c|}{ Değişkenler } & $\mathrm{n}$ & \multicolumn{2}{|l|}{$\%$} & \multicolumn{2}{|c|}{ Değişkenler } & $\mathbf{n}$ & $\%$ \\
\hline \multirow{4}{*}{$\begin{array}{c}\text { Medeni } \\
\text { Durum }\end{array}$} & \multirow{2}{*}{ Kadın } & Bekar & 226 & 71,7 & \multirow{12}{*}{ Gelir } & \multirow{6}{*}{ Kadın } & $0-1000 \mathrm{TL}$ & 121 & 38,4 \\
\hline & & Evli & 89 & 28,3 & & & $1001-2000 \mathrm{TL}$ & 16 & 5,1 \\
\hline & \multirow{2}{*}{ Erkek } & Bekar & 195 & 62,3 & & & $2001-3000 \mathrm{TL}$ & 74 & 23,5 \\
\hline & & Evli & 118 & 37,7 & & & 3001-4000 TL & 53 & 16,8 \\
\hline \multirow{8}{*}{ Yaş } & \multirow{4}{*}{ Kadın } & 20 yaş ve altı & 106 & 33,7 & & & $4001-5000 \mathrm{TL}$ & 29 & 9,2 \\
\hline & & $21-31$ yaş & 130 & 41,3 & & & 5001 TL ve üstü & 22 & 7,0 \\
\hline & & $32-42$ yaş & 40 & 12,7 & & \multirow{6}{*}{ Erkek } & $0-1000 \mathrm{TL}$ & 97 & 31,0 \\
\hline & & 43 yaş ve üzeri & 39 & 12,4 & & & $1001-2000 \mathrm{TL}$ & 10 & 3,2 \\
\hline & \multirow{4}{*}{ Erkek } & 20 yaş ve altı & 102 & 32,6 & & & 2001-3000 TL & 53 & 16,9 \\
\hline & & $21-31$ yaş & 105 & 33,5 & & & 3001-4000 TL & 60 & 19,2 \\
\hline & & $32-42$ yaş & 51 & 16,3 & & & $4001-5000 \mathrm{TL}$ & 39 & 12,5 \\
\hline & & 43 yaş ve üzeri & 55 & 17,6 & & & 5001 TL ve üstü & 54 & 17,3 \\
\hline \multirow{11}{*}{ Eğitim } & \multirow{5}{*}{ Kadın } & İlköğretim & 20 & 6,3 & \multirow{10}{*}{ Meslek } & \multirow{5}{*}{ Kadın } & Özel sektör çalışanı & 151 & 47,9 \\
\hline & & Lise & 140 & 44,4 & & & Kamu sektörü çalışanı & 27 & 8,6 \\
\hline & & Önlisans & 40 & 12,7 & & & Emekli & 5 & 1,6 \\
\hline & & Lisans & 100 & 31,7 & & & Öğrenci & 113 & 35,9 \\
\hline & & Lisansüstü & 15 & 4,8 & & & Çalışmıyor & 19 & 6,0 \\
\hline & \multirow{5}{*}{ Erkek } & İlköğretim & 18 & 5,8 & & \multirow{5}{*}{ Erkek } & Özel sektör çalışanı & 172 & 55,0 \\
\hline & & Lise & 162 & 51,8 & & & Kamu sektörü çalışanı & 18 & 5,8 \\
\hline & & Önlisans & 38 & 12,1 & & & Emekli & 18 & 5,8 \\
\hline & & Lisans & 79 & 25,2 & & & Öğrenci & 99 & 31,6 \\
\hline & & Lisansüstü & 16 & 5,1 & & & Çalışmıyor & 6 & 1,9 \\
\hline & \multicolumn{2}{|c|}{ Toplam } & 628 & 100 & & & oplam & 628 & 100 \\
\hline
\end{tabular}

Tablo 4. Cinsiyete Göre t-Testi Sonuçları

\begin{tabular}{|c|c|c|c|c|c|c|c|}
\hline \multicolumn{3}{|c|}{ Medeni Durum } & $\mathbf{n}$ & $\bar{X}$ & s.s. & $t$ & p \\
\hline \multirow{3}{*}{ Kadın } & 1.Fayda & $\begin{array}{c}\text { Bekar } \\
\text { Evli }\end{array}$ & $\begin{array}{c}226 \\
89\end{array}$ & $\begin{array}{l}3,75 \\
3,95\end{array}$ & $\begin{array}{l}0,65 \\
0,68\end{array}$ & $-2,436$ & 0,015 \\
\hline & 2.Değerlendirme & $\begin{array}{c}\text { Bekar } \\
\text { Evli }\end{array}$ & $\begin{array}{c}226 \\
89\end{array}$ & $\begin{array}{l}3,82 \\
3,42\end{array}$ & $\begin{array}{l}0,78 \\
1,12\end{array}$ & 3,058 & 0,003 \\
\hline & 4. Ekonomi & $\begin{array}{c}\text { Bekar } \\
\text { Evli }\end{array}$ & $\begin{array}{c}226 \\
89\end{array}$ & $\begin{array}{l}3,99 \\
3,42\end{array}$ & $\begin{array}{l}0,90 \\
1,06\end{array}$ & 4,765 & 0,000 \\
\hline
\end{tabular}

$p<0,05$

Kadın ve erkeklerin medeni durumlarına göre boş zamanı değerlendirme durumları istatistiksel olarak karşılaştırılmıştır. Karşılaştırma sonuçlarına göre, kadınların Fayda, Değerlendirme ve Ekonomi boyutlarında istatistiksel olarak anlamlı farklılıklar gözlemlenirken Kalite boyutunda anlamlı bir farklılığa rastlanılmamıştır. Evli kadınların bekar kadınlara oranla boş zamandan fayda sağlama puan ortalaması anlamda düzeyde yüksek çıkmıştır. Öte yandan bekar kadınların değerlendirme ve ekonomi boyutlarından edindikleri puan ortalamaları evli kadınlardan fazla çıkmıştır. Bekar kadınların ev dışında boş zamanlarını geçirme istekleri evli kadınlara oranla daha fazla olabilmektedir. Bu nedenle fayda boyutu sonucu anlaşlabilir bir durumdur. Evli kadınların ev içi boş zamanlarını değerlendirme konusunda bekar kadınlara oranla değerlendirme boyutundan düşük puan almış olmaları onların ev içerisinde fazlasıyla uğraşlarının olmasından kaynaklandığı söylenebilir. Evli kadınların boş zaman etkinliklerine daha az para harcayacakları düşünüldügünde ekonomi boyutunda çıkan sonuç anlaşılabilir bulunmuştur. 
Erkeklerin medeni durumlarına göre boş zamanı değerlendirme durumlarının karşılaştırması sonucu istatistiksel olarak anlamlı bir farklılığa ulaşılamamıştır.

"Hı: Kadınların medeni durum değişkenine göre boş zamanı değerlendirme davranışları arasında istatistiksel olarak anlaml bir farklılık vardır" hipotezi kabul edilmiştir.

“H2: Erkeklerin medeni durum değişkenine göre boş zamanı değerlendirme davranışları arasında istatistiksel olarak anlamlı bir farklılık vardır" hipotezi reddedilmiştir.

Tablo 5. Yaş Değişkenine Göre ANOVA Sonuçları

\begin{tabular}{|c|c|c|c|c|c|c|c|c|}
\hline & Yaş & & $\mathbf{n}$ & $\bar{X}$ & s.s. & $\mathbf{F}$ & $\mathrm{p}$ & Tukey \\
\hline \multirow{8}{*}{ Kadın } & \multirow{4}{*}{ 1. Fayda } & 20 yaş ve altı & 106 & 3,63 & 0,63 & \multirow{4}{*}{4,427} & \multirow{4}{*}{0,005} & \multirow{4}{*}{$\begin{array}{c}20 \text { yaş ve altı }<21-31 \text { yaş } \\
20 \text { yaş ve altı }<43 \text { yaş ve } \\
\text { üzeri }\end{array}$} \\
\hline & & 21-31 yaş & 130 & 3,86 & 0,68 & & & \\
\hline & & $32-42$ yaş & 40 & 3,91 & 0,52 & & & \\
\hline & & 43 yaş ve üzeri & 39 & 4,00 & 0,74 & & & \\
\hline & \multirow{4}{*}{ 4. Ekonomi } & 20 yaş ve altı & 106 & 4,03 & 0,92 & \multirow{4}{*}{3,342} & \multirow{4}{*}{0,020} & \multirow{4}{*}{$\begin{array}{c}20 \text { yaş ve altı }>43 \text { yaş ve } \\
\text { üzeri }\end{array}$} \\
\hline & & $21-31$ yaş & 130 & 3,73 & 1,01 & & & \\
\hline & & $32-42$ yaş & 40 & 3,90 & 0,95 & & & \\
\hline & & 43 yaş ve üzeri & 39 & 3,53 & 0,93 & & & \\
\hline \multirow{4}{*}{ Erkek } & \multirow{4}{*}{ 2. Değerlendirme } & 20 yaş ve altı & 102 & 2,56 & 0,92 & \multirow{4}{*}{3,125} & \multirow{4}{*}{0,026} & \multirow{4}{*}{$21-31$ yaş $>43$ yaş ve üzeri } \\
\hline & & $21-31$ yaş & 105 & 2,74 & 1,07 & & & \\
\hline & & $32-42$ yaş & 51 & 2,44 & 0,97 & & & \\
\hline & & 43 yaş ve üzeri & 55 & 2,27 & 0,87 & & & \\
\hline
\end{tabular}

$p<0,05=$ Anlaml

Kadın ve erkeklerin yaşlarına göre boş zamanı değerlendirme durumlarının karşılaştırılması sonucu istatistiksel olarak anlamlı farklılıklar tespit edilmiştir. Kadınların fayda ve ekonomi boyut puan ortalamaları istatistiksel olarak anlamlı bulunurken, Değerlendirme ve Kalite boyutları puan ortalamaları istatistiksel olarak anlamlı bulunmamıştır. Fayda boyutunda yaş arttıkça kadınların edindikleri puan ortalamasının da arttığı anlaşılmaktadır. Ekonomi alt boyutuna bakıldığında 20 yaş altındaki kadınların 43 yaş ve üzerindeki kadınlara oranla daha fazla puan aldıkları tespit edilmiştir. Bu durumların yaşın tecrübeyle doğru orantılı olmasından kaynaklandığı söylenebilir. Nitekim yaş arttıkça olaylara bakış açısı da olgunlaşabilmektedir.

Erkeklerin yaş gruplarına göre boş zamanı değerlendirme puan ortalamaları karşılaştırma sonuçlarına göre yalnızca değerlendirme alt boyutu anlamlı bulunmuştur. Buna göre, 21-31 yaş aralığındaki erkeklerin 43 yaş ve üzerindeki erkeklerden daha fazla bir puan ortalamasına sahip oldukları tespit edilmiştir. Evli erkeklerin hayatlarında bir rutini izledikleri düşünüldügüünde çıan sonuç kabul edilebilirdir.

"H3: Kadınların yaş değiş̧kenine göre boş zamanı değerlendirme davranışları arasında istatistiksel olarak anlamlı bir farklılık vardır." Hipotezi kabul edilmiştir.

“H4: Erkeklerin yaş değ̌işkenine göre boş zamanı değerlendirme davranışları arasında istatistiksel olarak anlamlı bir farklılık vardır." Hipotezi kabul edilmiştir.

Kadın ve erkeklerin eğitim durumlarına göre yapılan karşılaştırma sonucunda yalnızca kadınların Fayda boyutu puan ortalamaları arasında istatistiksel olarak anlamlı bir farklılık saptanmıştır. Söz konusu farklılığa göre, lisans düzeyindeki kadınların lise düzeyindeki kadınlara oranla daha fazla fayda puan ortalamasına sahip oldukları tespit edilmiştir. Eğitim seviyesinin artması bireylerin olaylara bakış açılarını değiştirebilmektedir. Öte yandan ev içerisinde fayda sağlayacak etkinliklerin belirlenmesi ve söz konusu etkinliklerin sağladığı 
faydaya bakış açısı da yine eğitim ile doğru orantılı olarak düşünüldüğünde çıkan sonuç anlaşılabilir bir durum olarak anlaşılabilir.

Tablo 6. Eğitim Değişkenine Göre ANOVA Sonuçları

\begin{tabular}{|c|c|c|c|c|c|c|c|}
\hline \multicolumn{2}{|c|}{ Eğitim } & $\mathbf{n}$ & $\bar{X}$ & s.s. & $\mathbf{F}$ & $p$ & Tukey \\
\hline \multirow{5}{*}{ Kadın 1. Fayda } & İlköğretim & 20 & 3,85 & 0,84 & \multirow{5}{*}{4,069} & \multirow{5}{*}{0,003} & \multirow{5}{*}{ Lise $<$ Lisans } \\
\hline & Lise & 140 & 3,68 & 0,64 & & & \\
\hline & Önlisans & 40 & 3,69 & 0,63 & & & \\
\hline & Lisans & 100 & 3,97 & 0,65 & & & \\
\hline & Lisansüstü & 15 & 4,12 & 0,53 & & & \\
\hline
\end{tabular}

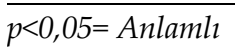

"H5: Kadınların eğitim değişkenine göre boş zamanı değerlendirme davranışları arasında istatistiksel olarak anlamlı bir farklılık vardır." hipotezi kabul edilmiştir.

"H6: Erkeklerin eğitim değişkenine göre boş zamanı değerlendirme davranışları arasında istatistiksel olarak anlamlı bir farklılık vardır." hipotezi reddedilmiştir.

Tablo 7. Gelir Değişkenine Göre ANOVA Sonuçları

\begin{tabular}{|c|c|c|c|c|c|c|c|c|}
\hline \multicolumn{3}{|c|}{ Eğitim } & $\mathrm{n}$ & $\bar{X}$ & s.s. & $\mathbf{F}$ & $\mathrm{p}$ & Tukey \\
\hline \multirow{6}{*}{\multicolumn{2}{|c|}{ 1. Fayda }} & $0-1000 \mathrm{TL}$ & 121 & 3,69 & 3,69 & \multirow{6}{*}{\multicolumn{2}{|c|}{$3,2940,006$}} & \multirow{6}{*}{$\begin{array}{c}0-1000 \text { TL }<4001-5000 \text { TL } \\
0-1000 \text { TL }<5001 \text { TL ve } \\
\text { üstü }\end{array}$} \\
\hline & & 1001-2000 TL & 16 & 3,86 & 0,67 & & & \\
\hline & & 2001-3000 TL & 74 & 3,75 & 0,65 & & & \\
\hline & & 3001-4000 TL & 53 & 3,83 & 0,64 & & & \\
\hline & & $4001-5000 \mathrm{TL}$ & 29 & 4,09 & 0,66 & & & \\
\hline & & 5001 TL ve üstü & 22 & 4,16 & 0,60 & & & \\
\hline \multirow{6}{*}{ Kadın } & \multirow{6}{*}{ 4. Ekonomi } & $0-1000 \mathrm{TL}$ & 121 & 4,05 & 0,92 & \multirow{6}{*}{\multicolumn{2}{|c|}{$4,1380,001$}} & \multirow{6}{*}{ 0-1000 TL $>3001-4000 \mathrm{TL}$} \\
\hline & & $1001-2000 \mathrm{TL}$ & 16 & 4,03 & 0,83 & & & \\
\hline & & 2001-3000 TL & 74 & 3,72 & 0,99 & & & \\
\hline & & 3001-4000 TL & 53 & 3,37 & 1,04 & & & \\
\hline & & 4001-5000 TL & 29 & 3,93 & 0,81 & & & \\
\hline & & 5001 TL ve üstü & 22 & 3,77 & 1,03 & & & \\
\hline
\end{tabular}

$p<0,05=$ Anlaml

Kadın ve erkeklerin gelir durumuna göre boş zamanı değerlendirme puan ortalamalarının karşılaştırılması sonucu erkeklerin puan ortalamalarında bir farklılık bulunmazken kadınların Fayda ve Ekonomi boyutlarındaki puan ortalamaları karşılaştırılmasında istatistiksel olarak anlamlı farklılıklar saptanmıştır. Buna göre, kadınların fayda boyutunda elde ettikleri puanların karşılaştırılmasında 4001-5000 TL ile 5001 TL ve üstü gelire sahip kadınların, 1000 TL altında gelire sahip kadınlara oranla daha fazla Fayda boyutu puan ortalamasına sahip oldukları anlaşılmıştır. Öte yandan Ekonomi boyutunda ise, 1000 TL altı gelire sahip kadınlar puan ortalaması, 3001-4000 TL gelire sahip kadınların puan ortalamasından yüksek çıkmıştır. Gelir durumu bireyin psikolojik rahatllğ 1 konusunda son derece önemli bir unsurdur. Nitekim ihtiyaçlar sıralamasının neredeyse her aşamasında paranın önemi tartışılmaz bir durum olarak gözlemlenmektedir. Bu bakımdan çok düşük gelire sahip bireylerin boş zamanlardan fayda sağlamaları da pek mümkün görülmemektedir. Öte yandan boş zaman faaliyetlerinin çok fazla ekonomik bir karşılığının olduğunu düşünenlerinde yine düşük gelire sahip olan bireylerden oluştuğunu söylemek mümkündür. 
"H7: Kadınların gelir değişkenine göre boş zamanı değerlendirme davranışları arasında istatistiksel olarak anlamlı bir farklılık vardır" hipotezi kabul edilmiştir.

"Hs: Erkeklerin gelir değişkenine göre boş zamanı değerlendirme davranışları arasında istatistiksel olarak anlamlı bir farklılık vardır "hipotezi reddedilmiştir.

Tablo 8. Meslek Değişkenine Göre ANOVA Sonuçları

\begin{tabular}{|c|c|c|c|c|c|c|c|c|}
\hline \multicolumn{3}{|c|}{ Eğitim } & $\mathrm{n}$ & $\bar{X}$ & s.s. & $\mathbf{F}$ & $\mathrm{p}$ & Tukey \\
\hline \multirow{5}{*}{\multicolumn{2}{|c|}{ 1. Fayda }} & Özel sektör çalışanı & 151 & 3,82 & 0,66 & \multirow{5}{*}{5,349} & \multirow{5}{*}{0,000} & \multirow{5}{*}{$\begin{array}{c}\text { Özel S.Ç.<Kamu sektörü ç } \\
\text { Kamu S.Ç.>Ö̈̆grenci } \\
\text { Kamu S.Ç.>Çalışmıyor }\end{array}$} \\
\hline & & Kamu sektörü & 27 & 4,28 & 0,50 & & & \\
\hline & & $\begin{array}{l}\text { çalişanı } 1 \\
\text { Fmekli }\end{array}$ & 5 & & & & & \\
\hline & & Öğrenci & 113 & 3,68 & 0,64 & & & \\
\hline & & Çalışmiyor & 19 & 3,70 & 0,77 & & & \\
\hline \multirow{5}{*}{ Kadin - } & \multirow{5}{*}{ 2. Değerlendirme } & Özel sektör çalışanı & 151 & 3,58 & 1,02 & \multirow{5}{*}{3,052} & \multirow{5}{*}{0,017} & \multirow{5}{*}{$\mathrm{p}>0,05$} \\
\hline & & Kamu sektörü & 27 & 4,09 & 0,66 & & & \\
\hline & & $\begin{array}{l}\text { çalışanı } \\
\text { Emekli }\end{array}$ & 5 & 3,93 & 1,04 & & & \\
\hline & & Öğrenci & 113 & 3,71 & 0,79 & & & \\
\hline & & Çalışmiyor & 19 & 4,11 & 0,64 & & & \\
\hline
\end{tabular}

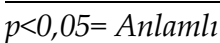

Kadın ve erkek katılımcıların mesleklerine göre yapılan karşılaştırma sonucuna göre, erkeklerin boş zamanı değerlendirme puan ortalama karşılaştırmasında istatistiksel olarak anlamlı bir farklılığa rastlanılmamıştır. Öte yandan kadınların sonuçları incelendiğinde fayda ve değerlendirme boyutları puan ortalamaları karşılaştırması istatistiksel olarak anlamlı bulunmuştur. Fakat yapılan Post Hoc-Tukey testi sonucu değerlendirme boyutu puan ortalamasının karşılaştırmasında fark 0,05 'ten büyük olduğundan farkı meydana getiren grubun hangisi olduğu belirlenememiştir. Fayda boyutunda ise, kamu sektöründe çalışan kadınların özel sektör çalışanları, öğrenci ve çalışmayan grupta yer alan kadınlardan fazla bir puan ortalamasına sahip oldukları ortaya çıkmıştır. Kamu sektöründe çalışan kadınların pandemi sürecinde daha az çalışma saatlerine sahip olmaları boş zamanlardan fayda sağlama düşüncelerini de olumlu yönde etkilediğini söylemek mümkündür. Bu nedenle kamu sektöründe çalışan kadınların özel sektör çalışanları veya kadın öğrencilere oranla yüksek puan ortalamasına sahip olmaları anlaşllabilir bir sonuçtur.

"H9: Kadınların meslek değişkenine göre boş zamanı değerlendirme davranışları arasında istatistiksel olarak anlamlı bir farklılık vardır." hipotezi kabul edilmiştir.

"H10: Erkeklerin meslek değişkenine göre boş zamanı değerlendirme davranışları arasında istatistiksel olarak anlamlı bir farklllık vardır." hipotezi reddedilmiştir.

Kadın ve erkeklerin boş zaman faaliyetlerine katılım sıklıklarına bakıldığında kadınların erkeklere oranla daha aktif oldukları söylenebilir. Nitekim 3-4-7-9-10-14-16-20 ve 24'üncü faaliyetlere erkeklerin kadınlara oranla daha sık katıldıkları görülse de genel anlamda kadınların diğer 20 boş zaman faaliyetine daha sık katıldıkları tespit edilmiştir. Söz konusu kadın ve erkeklerin boş zaman faaliyetlerine katılım sıklıklarına bakıldığında en belirgin fark "müzik dinlerim", "dizi/film izlerim" ve ailemle zaman geçiririm" faaliyetlerinde ortaya çıkmaktadır. Erkekler açısından bakıldığında ise en belirgin fark "spor müsabakası izlerim" faaliyeti şeklinde ortaya çıkmıştır. Bu sonuçların toplumsal yapı içerisinde kadın ve erkeklerin ilgi alanlarının belirgin özelliklerinden kaynaklandığı düşünülmektedir. 
Tablo 9. Boş Zaman Faaliyetleri Katılım Sıklığı

\begin{tabular}{|c|c|c|c|c|c|}
\hline \multirow{2}{*}{ İfadeler } & \multirow{2}{*}{ Min } & \multirow{2}{*}{ Max } & \multirow{2}{*}{ Ort. } & \multicolumn{2}{|c|}{$\begin{array}{c}\text { Cinsiyete göre } \\
\text { Ortalama }\end{array}$} \\
\hline & & & & Kadın & Erkek \\
\hline 1.Boş zamanlarımı sosyal medyada geçiririm. & 1 & 5 & 3,39 & 3,45 & 3,33 \\
\hline 2.Boş zamanlarımda online platformlarda alışveriş yaparım. & 1 & 5 & 2,37 & 2,67 & 2,07 \\
\hline 3.Boş zamanlarımda evde oyun türlerini oynarım. & 1 & 5 & 2,31 & 2,03 & 2,58 \\
\hline 4.Boş zamanlarımda TV izlerim. & 1 & 5 & 2,65 & 2,59 & 2,72 \\
\hline 5.Boş zamanlarımda ders çalışırım. & 1 & 5 & 2,35 & 2,43 & 2,27 \\
\hline 6.Boş zamanlarımda evden işimi yaparım. & 1 & 5 & 2,44 & 2,55 & 2,33 \\
\hline 7.Boş zamanlarımda egzersiz/spor yaparım. & 1 & 5 & 2,57 & 2,45 & 2,68 \\
\hline 8.Boş zamanlarımda sanatla ilgilenirim. & 1 & 5 & 2,14 & 2,22 & 2,06 \\
\hline 9.Boş zamanlarımda ev tadilatı yaparım. & 1 & 5 & 2,02 & 1,83 & 2,21 \\
\hline 10.Boş zamanlarımda ibadet ederim. & 1 & 5 & 2,60 & 2,49 & 2,71 \\
\hline 11.Boş zamanlarımda seyahate-tatile çıkarım. & 1 & 5 & 1,99 & 2,00 & 1,97 \\
\hline 12.Boş zamanlarımda el işi yaparım. & 1 & 5 & 1,59 & 1,85 & 1,32 \\
\hline 13.Boş zamanlarımda kitap/gazete/dergi vb. yayınları okurum. & 1 & 5 & 2,95 & 3,14 & 2,77 \\
\hline 14.Boş zamanlarımda müzik icra ederim. & 1 & 5 & 2,08 & 2,00 & 2,16 \\
\hline 15.Boş zamanlarımda müzik dinlerim. & 1 & 5 & 3,69 & 3,95 & 3,43 \\
\hline 16.Boş zamanlarımda bahçe işleri ile uğraşırım. & 1 & 5 & 1,88 & 1,83 & 1,93 \\
\hline 17.Boş zamanlarımda yemek yaparım. & 1 & 5 & 2,86 & 3,43 & 2,30 \\
\hline 18.Boş zamanlarımda online kurslara katılırım. & 1 & 5 & 1,98 & 2,08 & 1,88 \\
\hline 19.Boş zamanlarımda online sanat gösterilerine katılırım. & 1 & 5 & 1,39 & 1,43 & 1,35 \\
\hline 20.Boş zamanlarımda çocuklarla oyun oynarım. & 1 & 5 & 2,40 & 2,38 & 2,42 \\
\hline 21.Boş zamanlarımda online platformlarda dizi/film izlerim. & 1 & 5 & 3,42 & 3,62 & 3,21 \\
\hline 22.Boş zamanlarımda kişisel bakımımla ilgilenirim. & 1 & 5 & 3,32 & 3,71 & 2,92 \\
\hline 23.Boş zamanlarımda temizlik yaparım. & 1 & 5 & 2,97 & 3,46 & 2,49 \\
\hline 24.Boş zamanlarımda spor müsabakası izlerim. & 1 & 5 & 2,43 & 1,74 & 3,13 \\
\hline 25.Boş zamanlarımda ailemle zaman geçiririm. & 1 & 5 & 3,61 & 3,76 & 3,46 \\
\hline 26.Boş zamanlarımda uyurum. & 1 & 5 & 2,81 & 2,89 & 2,73 \\
\hline 27.Boş zamanlarımı yarım kalan işlerimi tamamlamak için kullanırım. & 1 & 5 & 3,31 & 3,51 & 3,11 \\
\hline 28.Boş zamanımı online toplantılarda sosyalleşerek geçiririm. & 1 & 5 & 1,94 & 2,04 & 1,84 \\
\hline 29.Boş zamanımı mesajlaşma programlarında sosyalleşerek geçiririm. & 1 & 5 & 3,21 & 3,43 & 2,98 \\
\hline
\end{tabular}

1=Hiçbir zaman 2=Nadiren $3=$ Ara sıra $4=C ̧ o k$ sik $5=$ Her zaman

“Hı: Kadın ve erkeklerin boş zaman faaliyetlerine katılım sıklıkları arasında farklılık vardır." Hipotezi kabul edilmiştir.

\section{TARTIŞMA ve SONUÇ}

Pandemi sürecinde sokağa çıkma yasaklarının getirilmesiyle evde geçen boş zaman süreleri artmıştır (Roberts, 2020: 619). İnsanlar evde farklı farklı boş zaman faaliyetleri ile meşgul olabilmek durumunda kalmışlardır. Bu durum bazı gruplarda olumlu sonuçlar gösterirken bazı gruplarda ise olumsuz birtakım sonuçlar ortaya çıkarmıştır. Bireylerin pandemi sürecinde ev içi boş zamanlarını nasıl algıladıkları ve değerlendirdikleri önemli olduğundan bu araştırma yapılmıştır. Elde edilen bulgular alan yazınla tartışılarak mevcut tablo gözlemlenmeye çalışılmıştır.

Araştırmada elde edilen bulgulara göre evli kadınların bekâr kadınlara göre fayda boyutu puan ortalamasının anlamlı düzeyde yüksek çıktı̆̆ı tespit edilmiştir. Ayrıca bekâr kadınların değerlendirme boyutunda evli kadınlara göre puan ortalamaları daha yüksek çıkmışır. Bu durum evli kadınların boş zamanları değerlendirmede daha başarılı oldukları sonucunu düşündürmektedir. Evli kadınların ev içi boş zaman değerlendirme durumlarında algıladıkları fayda düzeyinin bekarlara oranlara yüksek çıkmış olması ev içi tercih etmiş oldukları 
etkinliklerden kaynaklandığ1 düşünüldüğünde, Marques ve Giolo (2020: 347)'nun pandemi süreciyle ilgili yapmış oldukları çalışmada dijital ve kültürel etkinliklere yönelik platformların artması ve çeşitlenmesinin evde geçirilen sürede sağlanan faydanın arttığı sonucu söz konusu varsayımı destekler niteliktedir. Öte yandan evli kadınların değerlendirme boyutunda bekar kadınlara oranla daha düşük puan almış olmaları ev içerisinde sahip oldukları sorumluluklarının daha fazla olmasından kaynaklandığı düşünülmektedir. Ekonomik açıdan değerlendirildiğinde ise, erkeklerde istatistiksel olarak anlamlı bir bulguya ulaşılmazken kadınlarda istatistiksel olarak anlamlı bir sonuca ulaşılmıştır. Bu durumda bekar kadınların evli kadınlara oranla boş zamanı değerlendirmede ekonomik boyutun yüksek olması gerektiği düşüncesinde oldukları sonucuna ulaşılmıştır. Yani bekar kadınlar boş zamanlardaki etkinlikler için daha fazla paraya ihtiyaç duyulduğu fikrine sahiptirler. Bu durum şu şekilde açıklanabilir. Evli çalışmayan kadınların eşlerinden ekonomik anlamda destek gördükleri söylenebilir ve çalışan evli kadınların hanelerine birden fazla maaş girdisi sağlayabildikleri düşünüldügüünde bekar kadınlara oranla bu konuda daha avantajlı bulunacakları söylenebilir. Nitekim evli kadınların yapacağı etkinliğin ekonomik yükünü eşleriyle paylaştıklarından, bekar kadınlar kadar bu durumdan etkilenmeyecekleri söylenebilir.

Kadınların yaşları arttıkça fayda boyutu puan ortalamalarının da arttığı görülmüştür. Bu sonuca göre, pandemi sürecinde kısıtlamaların çokluğu ve evde kalma zorunluluğuyla birlikte bu araştırmadaki yaş gruplarına göre en fazla etkilenen grubun 20 yaş altındakiler olduğu bulgusuna ulaşılmıştır. Yani ev içi boş zamanlardan memnun olmadıkları ve bu boş zamanlarda ev içerisinde gerçekleştirdikleri boş zaman faaliyetlerinden daha az mutlu oldukları anlaşılmıştır (bkz. Tablo 5). Son ve diğerlerinin (2020:6) pandemiye yönelik yapmış oldukları araştırma sonuçlarına göre, ileri yaştaki bireylerin pandemi nedeniyle daha fazla risk altında bulunmuştur. Bunun sonucunda kısıtlamalardan daha fazla etkilenmelerine neden olmuştur. Sürekli evde kalmak ev içi boş zamanlardan daha az memnun olmaya neden olmasının yanı sıra sağlık sorunlarına da neden olabilmektedir. Bu açıdan uzmanların söz konusu ileri yaş gruplarına egzersiz tavsiyelerinin olduğu ifade edilmiştir. Pandemi nedeniyle sürekli olarak evde bulunmamın ve hareket etmemenin zararlı sonuçları açıkça gözlemlenmektedir (Lawanson, 2020: 2). Psikolojik olarak gençler daha fazla etkileniyor gibi görünse de tüm yaş gruplarının bu durumdan etkilendikleri söylenebilir.

Ekonomi boyutunda ise, 20 yaş altındaki kadınların 43 yaş ve üzerine göre daha fazla puan alması, 20 yaş altı kadınların 43 yaş ve üzerine göre gelirlerinin daha az veya hiç olmamasından kaynaklandığı söylenebilir. Erkeklerin boş zaman değerlendirme durumları incelendiğinde istatistiksel olarak anlamlı bir sonuca ulaşılmıştır. Buna göre, değerlendirme boyutunda en az puanı alan 43 yaş ve üzeri grubun boş zamanı nasıl değerlendireceği konusunda genç yaştaki erkeklere oranla daha başarılı oldukları ifade edilebilir. Nitekim 43 yaş ve üzerindekilerin iş hayatında oldukları ve evde yani uzaktan işlerini sürdürebildikleri düşünüldüğünde değerlendirmeleri gereken boş vakitlerinin daha az olmasına bu durumunda söz konusu zaman dilimlerinde yapacak bir etkinlik bulmayı kolaylaştırdığı düşünülmektedir.

Eğitim değişkenine göre boş zamanı değerlendirme durumlarına bakıldığında erkek katılımciların puan ortalamaları arasında istatiksel olarak anlamlı bir bulguya rastlanılmazken kadınlarda fayda boyutunda istatistiksel olarak anlamlı bir sonuca ulaşılmıştır. Bu sonuca göre COVID-19 sürecinde lisans eğitim seviyesinde olanların lise düzeyindekilere oranla ev içi boş zamanlarından daha memnun oldukları ve boş zamanlarda yaptıkları etkinliklerden daha mutlu oldukları anlaşılmaktadır. Pandemiyle birlikte artan boş zamanlar (Roberts, 2020: 619) ve bu boş zamanlardan memnun olunacak, söz konusu zamanları dolduracak bilgiye lisans seviyesindekilerin sahip oldukları bunun nedeninin ise etkinlik seçimlerini çok yönlü araştırma yapma bilgisine sahip olarak elde ettikleri bu bulgunun nedeni olarak düşünülebilir. 
Gelir değişkenine göre erkeklerde bir farklılı̆ga ulaşılamazken kadınlarda istatistiksel olarak anlamlı bulgular tespit edilmiştir. Kadınların fayda boyutu ve ekonomi boyutunda gözlemlenen sonuçları incelendiğinde gelir seviyesinin düşük olmasının olumsuz sonuçlar doğurduğu saptanmıştır. Nitekim gelir seviyesi 1000 TL ve altı olanların boş zamanlarından memnun olmadıkları anlaşılmaktadır. Bunun nedeni olarak geçim sorunlarının neden olduğu düşünülebilir. Demir ve Demir (2006)'in çalışmasına göre üniversite öğrencilerinde gelir durumu, boş zaman etkinliklerine katılmada önemli faktörler arasında yer almaktadır. Bu durumda geliri az olan kadınların, geliri yetmediği için bazı boş zaman aktivitelerini gerçekleştiremedikleri düşünülebilir. Bu sonuç çalışma bulgumuzu destekler niteliktedir.

Katılımcıların mesleklerine göre boş zamanı değerlendirme algıları incelendiğinde erkeklerde bir farklılığa ulaşılmazken kadınlarda fayda boyutunda bir farklılığa ulaşılmıştır. Pandemi sürecinde kadın ve erkek fark etmeksizin herkesin evlerinde kalmaları gerekmiştir. Bu anlamda özel sektörde çalışmak zorunda olanların çoğu işlerinden ayrılmak zorunda bırakılmışlardır. Bunun sonucunda gelirleri kesilen ve geçim sorunları yaşayan bireylerin mutsuzlaştıkları anlaşılmaktadır. Elde edilen bulgu bunu doğrular niteliktedir (bkz. Tablo 8). Kamuda çalışan kadınların söz konusu kısıtlamalara rağmen gelirlerinin kesilmemesi ev içerisindeki boş zamanlarını diğer meslek gruplarına göre olumsuz anlamda çok etkilememektedir.

Pandemi sürecinde kadın ve erkeklerin sokağa çıkma kısıtlamalarından ötürü ev içi boş zaman sürelerinde ciddi bir artış gözlemlenmiş ve bu süreler içerisinde ev içindeki boş zaman değerlendirme tercihlerinde geçirdikleri sürelerde buna paralel olarak artmıştır (Roberts, 2020: 621). Yapılan bu araştırma bulguları incelendiğinde kadın ve erkeklerin birçok farklı boş zaman tercihine farklı sıklıklarda katıldıkları saptanmıştır. Öte yandan kadınların erkeklere oranla boş zaman katılım sıklıklarının etkinlik bazında daha yüksek olduğu anlaşılmıştır. Alan yazın taramasında boş zaman etkinliklerine katılım durumlarına göre çok yönlü sonuçların olduğu anlaşılmaktadır (Aslan, 2001; Mansuroğlu, 2002; Aydoğan ve Gündoğdu, 2006; Özdemir ve Yaman, 2007; Sabbağ ve Aksoy, 2011; Aslan ve Cansever, 2012; Koçer, 2013; Kurar ve Baltac1, 2014; Akyüz ve Türkmen, 2016; Bekir, 2019; Korkutata vd., 2019). Dolayısıyla bu sonuçların araştırma bulgularımızla örtüştüğünü söylemek mümkündür.

Pandemi sürecinde evde geçirilen boş zamanlarda erkeklerin kadınlara göre evde boş zaman etkinliklerinden evde oyun türlerini oynama, TV izlemek, egzersiz/spor yapmak, ev tadilatı yapmak, ibadet etmek, müzik icra etmek, bahçe işleri ile uğraşmak, çocuklarla oyun oynamak ve spor müsabakası izlemek etkinliklerini daha çok gerçekleştirdikleri anlaşılmıştır. Kadınların ise en belirgin farkla erkeklere göre daha çok müzik dinleme, dizi/film izleme ve aile ile vakit geçirme etkinliklerini tercih ettiği ifade edilebilir. Aydoğan ve Gündoğdu (2006)'nun çalışmasının sonuçlarına göre kadınların hayatlarındaki ilk önceliği aileleri olarak ifade edilmiştir. Bu anlamda kadınların aileleri ile vakit geçirme etkinliğini daha sık gerçekleştirmesi sonucunu destekler niteliktedir. Ayrıca çalışmalarında kadınların boş zamanlarında çoğunlukla yemek ve temizliğin yanı sıra gazete, kitap, dergi okuduklarını ve TV/video izledikleri ortaya koyulmuştur. Araştırma sonuçlarımızla benzerlik gösterdiği söylenebilir. Aslan (2001)'ın çalışmasının sonuçlarına göre kadınların kitap okumayı daha çok tercih ettiği görülmektedir. Bu sonuçlar araştırma bulgusunu desteklemektedir. Kadınların erkeklere göre alışverişi daha sık gerçekleştirdiği belirlenmiştir. Özdemir ve Yaman (2007)'ın araştırmasına göre kadınların erkeklere göre alışverişten daha fazla zevk aldığ 1 ifade edilmektedir. Buna göre elde edilen sonucu destelemektedir. Araştırma sonuçlarına göre erkekler evde oyun türlerini oynama etkinliğini daha sık gerçekleştirmektedir. Evde gerçekleştirilen oyun türlerinin çoğu çevrimiçidir. Bekir (2019)'in araştırmasına göre erkeklerin çevrimiçi oyun bağımlılığı kadınlara göre daha yüksektir. Bu sonucun araştırma bulgumuzla örtüştüğü düşünülmektedir. Televizyon izleme etkinliğinin cinsiyete göre farklılaştığı belirlenmiştir. Bu sonucu destekler nitelikte Koçer 
(2013)'in çalışmasında da televizyon izleme alışkanlığ ortaya konulmuştur. Egzersiz/spor etkinliğine katılım sıklığında cinsiyete göre farklılaşma olduğu görülmektedir. Sabbağ ve Aksoy (2011)'un araştırmasında da cinsiyete göre spor etkinliğine katılım sıklığında farklılaşma olduğu söylenebilir. Bu anlamda araştırma sonucunu desteklemektedir. Kurar ve Baltacı (2014) yaptıkları çalışmada kişilerin gazete ve dergi okumak ve internette vakit geçirmek faaliyetlerine önemli oranda katılım gösterdiklerini belirlemiştir. Bu araştırmanın sonuçlarına göre de kişilerin kitap/gazete/dergi vb. yayınları okumak ve sosyal medyada vakit geçirmek etkinliklerine katılım sıklığı önemli orandadır. Kişilerin sanatsal etkinliklere katılım sıklıkları $(1,39)$ düşük olduğu görülmektedir. Benzer şekilde Akyüz ve Türkmen (2016)'in üniversite öğrencileri ile yaptığı çalışmasında da kişilerin boş zamanlarında sanatsal faaliyetlere katılımı düşük oranda olduğu belirlenmiştir.

Katılımcların ders çalışmak $(2,35)$ ve evden iş yapmak $(2,44)$ etkinliklerini düşük sıklıkta gerçekleştirdiği belirlenmiştir. Online kurslara katılım $(1,98)$ sıklıklarının da düşük olduğu söylenebilir. Buna göre insanların evde geçirdikleri boş zamanlarında eğitici ve öğretici etkinlikleri genellikle tercih etmedikleri ifade edilebilir. Benzer şekilde seyahat-tatile çımak $(1,99)$ etkinliğinin gerçekleştirilme sıklığı da çok düşüktür. Pandemi sürecinde sokağa çıkma yasaklarının yaşanması bu konuda bir engel olabilir. Aynı zamanda insanların işlerini kaybetmesi de ekonomik yönden olumsuz bir etki yaratacağı için seyahat gibi gelir gerektiren etkinliklere katılım az olabilmektedir. Online toplantılara katılım $(1,94)$ sıklı̆̆ı düşüktür. Bu durumun sokağa çıkma yasaklarının hafta sonu ve genellikle tatil günü olmasından dolayı meydana geldiği düşünülebilir. Çünkü online toplantı platformları genellikle çalışan kesim tarafından daha çok kullanılmaktadır. Bu dönemde insanların uyumayı $(2,81)$ çok sık tercih etmediği, yarım kalan işlerini tamamlama $(3,31)$ konusunda ise daha sık harekete geçtikleri ifade edilebilmektedir. Mesajlaşma programlarında sosyalleşme $(3,21)$ etkinliğine katılım sıklığ önemli bir oranda gerçekleştirilmektedir. Pandemi sürecinde insanların çok fazla bir araya gelememesi dolayısıyla buna yönelim olabileceği düşünülebilir. Genel olarak katılımcıların boş zaman etkinliklerine katılım sıklıkları değerlendirildiğinde kişilerin boş zamanlarında gerçekleştirdikleri etkinliklere orta düzeyde katılım gösterdiği ifade edilebilir. Söz konusu boş zaman etkinlikleri arasında en dikkat çekici etkinliklerden bazıları internet ortamında gerçekleştirilebilen etkinlikler olarak göze çarpmaktadır. Sağar ve Ateş (2021)'in çalışmasında internet bağımlılığının olumsuz etkilerinden sıkça söz edilmekte, bu yönde değerlendirildiğinde katılımcıların bu tür etkinliklerin olumsuz sonuçlarından etkilenebileceği düşünülebilir.

Araştırmanın yapıldığı dönemi kapsayan pandemi, ekonomiden eğitime kadar pek çok alanda etkilerini hissettirmiştir. İşi olan insanların çoğunun iş yerleri kapatılmış, işsiz kalınmış veya ücretsiz izne ayrılmak zorunda bırakılmışlardır. Öğrenciler, okulları kapalı olduğu için evde uzaktan eğitime başlamışlardır. Öte yandan COVID-19 pandemisinde getirilen sokağa çıma kısıtlamaları olmuş ve de insanlar sosyal izolasyona geçmiştir. Bu açıdan evde geçirilen boş zamanlar artış göstermiştir. Salgın öncesi insanlar, boş zamanlarını ev dişında pek çok farklı etkinlik ile geçirebilmekteydi. Pandemiyle birlikte bu durum ev içerisinde gerçekleştirilebilecek faaliyetlere dönüşmüştür. Normal zamanda daha az süre yapılan veya hiç yapılmayan etkinlikler daha fazla yapılmaya başlanmıştır (Roberts, 2020: 619). Böylece insanların evdeki boş zamanlarını değerlendirmelerine yönelik olumlu veya olumsuz tutumları da ortaya çımıştır.

Araştırma sonuçları pandeminin çeşitli olumsuz sonuçlarını açıkça göstermiştir. Öte yandan araştırmanın amacına ulaşılmışır. Nitekim boş zaman değerlendirme durumu kadın ve erkeklere göre farklılık göstermiştir. Tercih edilen etkinlikler bazında da farklılıklar net bir şekilde gözlemlenebilmektedir. Araştırma sonuçlarına göre aşağıdaki öneriler getirilebilmektedir.

Sektöre öneriler: 
- Rekreasyon işletmeleri, evde yapılabilecek ve ekonomik olabilecek rekreatif faaliyetler türetip bunları bireylerle paylaşabilir veya çevrimiçi ortamlarda gerçekleştirmelerini sağlayabilirler. Örneğin, online konser, online festival, online seyahat, online egzersiz gibi örneklendirilebilir.

- Rekreatif faaliyetleri gerçekleştiren işletmelerin, online / çevrimiçi faaliyetleri hızlı ve güvenli sunmak üzere teknolojik yatırım yapması önerilmektedir (veri madenciliğine ve kullanıcı dostu mobil uygulamalara yönelik özel yazılımlar, sosyal medya içerikleri, özel donanım geliştirmek vb.)

- Çevrimiçi mecralara evrilen rekreatif faaliyetlerin internet üzerinden satın alma işlemlerinin hızlı ve güvenli olabilmesi için güvenli ödeme ve teslimat sistemleri geliştirilmesi, sahte hesap ve sahte uygulamalara ilişkin siber suçlar konusunda da devletin yaptırımları arttırması önerilmektedir. Pandemi sürecinde online uygulamalar, ödemeler, üyelikler ve satışlar konusunda çok fazla dolandırıcılık gerçekleştiği medyada sıkça yer almıştır.

- Boş zamanı değerlendirmek isteyen bireylerin demografik, sosyolojik, psikolojik ve ekonomik özelliklerine göre "kişiselleştirilmiş" pazarlama karması ve içerik geliştirilmesi önerilmektedir. Bu bağlamda farklı demografik özelliklerinden kaynaklı olarak beklenti ve ihtiyaçları farklı olan bireylere kişiselleştirilmiş online spor dersi, online resim - el işi, online rekreatif aktiviteler geliştirilmesi önerilmektedir. Bunun için iyi bir veri madenciliği alt yapısı ve veri yönetimi gerekmektedir. Örneğin medeni durumuna göre, ekonomik durumuna göre, yaş aralığına göre hedef kitle segmentasyonu ile kişiye özel içerik geliştirmek vb.

Kamuya öneriler:

- Devlet, insanların evde daha farklı aktivitelerle meşgul olacakları rekreatif faaliyetleri teşvik edebilir. Bu konuda ücretsiz mecralar (sanal müze, sanal gezi, sanal kültür çalışmaları, sanal spor vb.) önerilmektedir. İlgili bakanlıklar bu durumun ana paydaşı olmalıdır.

- Türkiye nüfusunun demografik, ekonomik, psikolojik, ekonomik ve sosyolojik yapısı dikkate alınarak, alt grupların boş zamanlarını değerlendirmeye yönelik ihtiyaç ve beklentilerinin ortaya çıkarılmasına yönelik Türkiye genelinde geniş çaplı istatistiksel çalışmalar yapılması önerilmektedir. Bu türlü verilerin piyasa ile paylaşılabilir bilgiye dönüştürülmesi sağlanmalıdır.

- İnsanlar, ücretsiz online sanat gösterilerine ve online kurslara çeşitli reklam kampanyalarıyla teşvik edilerek evlerde geçirilen boş zamanı değerlendirmede faydalı aktivitelere yönlendirilebilir.

Gelecek araştırmalar için öneriler:

- Farklı bir ülkede bu araştırma yapılarak ülkelere göre boş zamanı değerlendirme konusunda farklılık ya da benzerlikler olup olmadığı araştırılabilir.

- Bu araştırma pandemi sonrası da uygulanarak pandeminin boş zaman etkinliklerinde kalıcı bir değişim gerçekleştirip gerçekleştirmediği incelenebilir.

- Elde edilen bulgulardan yola çıarak, bu tür kriz zamanlarında boş zamanını değerlendirme konusunda kısıtlanmış ve ne yapacağı konusunda yaratıcılığını kullanamayan ve bütçesini ayıramayan birey ve grupların tespiti yapılıp, toplumun ruh sağlı̆̆ını ve hane içerisinde bireylerin aile birliğini korumak ve boş zamanlarını verimli kullanabilmeleri adına devletin ilgili kuruluşları yapılacak ekonomik ve fayda sağlayıcı rekreatif faaliyetler ve etkinlikler geliştirebilir.

\section{KAYNAKÇA}

Akgül, B. M. (2011). Farklı Kültürlerdeki Bireylerin Boş Zaman Aktivitelerine Yönelik Tutumlarının Değerlendirilmesi: Ankara-Londra Örneği, Yayınlanmamış Doktora Tezi, Gazi Üniversitesi, Ankara. 
Akyüz, H. ve Türkmen, M. (2016). Üniversite Öğrencilerinin Boş Zaman Faaliyetlerine Yönelik Tutumlarının İncelenmesi: Bartın Üniversitesi Örneği. International Journal of Science Culture and Sport (IntJSCS), 4(1), 340-357.

Altunışık, R., Çoşkun, R., Bayraktaroğlu, S. ve Yıldırım, E. (2007). Sosyal Bilimlerde Araştırma Yöntemleri (5. Baskı). Sakarya Yayıncılık, İstanbul.

Arslan, S. (2013). (Yetişkin Eğitimi Bakı̧̧ Açısılla) Serbest Zaman-Rekreasyon ve Serbest Zaman Eğitimi. Ankara: Nobel Yayın.

Aslan, İ. (2001). Van İlinde Görevli Farkh Meslek Gruplarında Çalışan Bireylerin Boş Zamanlarını Değerlendirme Alışkanlıklarının Araştırılması, Yayınlanmamış Yüksek Lisans Tezi, Yüzüncü Yıl Üniversitesi, Van.

Aslan, N., ve Cansever, B. A. (2012). Ergenlerin Boş Zaman Değerlendirme Algısı. Mehmet Akif Ersoy Üniversitesi Sosyal Bilimler Enstitüsü Dergisi, 42, 23-35.

Aydoğan, İ., ve Gündoğdu, B. (2006). Kadın Öğretim Elemanlarının Boş Zamanlarını Değerlendirme Etkinlikleri. Erciyes Üniversitesi Sosyal Bilimler Enstitüsü Dergisi, 21 (1), 217-232.

Aytaç, Ö. (2017). İşlevselci Yaklaşım Açısından Boş Zaman Sosyolojisi: Kurumlar, Süreçler, Etkinlikler. S. Karaküçük, S. Kaya, ve B. M. Akgül (Dü) içinde, Rekreasyon Bilimi. Ankara: Gazi Kitabevi.

Bagozzi, R. P. and Yi, Y. (1988). On the evaluation of structural equation models. Journal of the Academy of Marketing Science, 16(1), 74-94.

Bekir, S. (2018). Üniversite Öğrencilerinde Çevrimiçi Oyun Bağımlılığı Düzeyinin Duygusal Şemalar, Eylemli Kişilik ve Bazı Değişkenler Açısından İncelenmesi, Yayınlanmamış Yüksek Lisans Tezi, Sakarya Üniversitesi, Sakarya.

Budak, F., ve Korkmaz, Ş. (2020). Covid-19 Pandemi Sürecine Yönelik Genel Bir Değerlendirme: Türkiye Örneği. Sosyal Araştırmalar ve Yönetim Dergisi (SAYOD)(1), 62-79.

Brown, S. (2016). Measures of Shape: Skewness and Kurtosis. Oak Road Systems. https://brownmath.com/stat/shape.htm (26.03.2021)

Cao, W., Fang, Z., Hou, G., Han, M., Xu, X., Dong, J., and Zheng, J. (2020). The psychological impact of the COVID-19 epidemic on college students in China. Psychiatry Research. 287, 1-5, 112934. DOI: 10.1016/j.psychres.2020.

Chen, I.-S. (2020). Turning Home Boredom during the Outbreak of COVID-19 into Thriving at Home and Career Self-Management. International Journal of Contemporary Hospitality Management. 32(11), 3645-3663, DOI: 10.1108/IJCHM-06-2020-0580

Cheval, B., Sivaramakrishnan, H., Maltagliati, S., Fessler, L., Forestier, C., Sarrazin, P., Orsholits, D., Chalabaev, A., Sander, D., Ntoumanis, N., Boisgontier, M. P. (2020). Relationships Between Changes in Self-Reported Physical Activity, Sedentary Behaviours and Health During the Coronavirus (COVID-19) Pandemic in France and Switzerland. Journal of Sports Sciences, 39(6), 699-704.

Creswell, J. W. (2013). Research Design: Qualitative, Quantitative, And Mixed Methods Approaches. New York: Sage.

Çakır, O. (2017). Rekreasyon Kavramı ve Teorileri. M. A. Kozak (Dü.) içinde, Rekreasyonel Liderlik ve Turist Rehberliği. Ankara: Detay Yayıncılık. 
Douglas, L. and Connor, R. (2003). Attitudes to Service Quality- the Expectation Gap. Nutrition and Food Service, 33(4), 163-172.

Demir, C., ve Demir, N. (2006). Bireylerin Boş Zaman Faaliyetlerine Katılmalarını Etkileyen Faktörler İle Cinsiyet Arasındaki İlişki: Lisans Öğrencilerine Yönelik Bir Uygulama. Ege Akademik Bakış Dergisi, 6(1), 36-48.

Ekinci, N. E., and Ozdilek, C. (2019). Investigation of University Students' Awareness of Recreational Activities, International Online Journal of Educational Sciences, 11(2), 53-66.

Fornell, C. and Larcker, D.F. (1981). Evaluating Structural Equation Models with Unobservable Variables and Measurement Error. Journal of Marketing Research, 18(1), 39-50.

Hacıŏ̆lu, N., Gökdeniz, A., ve Dinç, Y. (2015). Boş Zaman ve Rekreasyon Yönetimi. Ankara: Detay Yayıncilık.

Hair, J. F., Risher, J. J., Sarstedt, M., and Ringle, C. M. (2019). When to use and how to report the results of PLS-SEM. European Business Review, 31(1), 2-24.

Juniu, S. (2000). Downshifting: Regaining the Essence of Leisure. Journal of Leisure Research, 32(1), 69-73.

Karaküçük, S. (2001). Rekreasyon Boş Zamanları Değerlendirme. Ankara: Gazi Kitabevi.

Karasar, N. (1994). Bilimsel Araştırma Yöntemi: Kavramlar, İlkeler, Teknikler (5. Baskı). Ankara: 3A Eğitim Danışmanlık.

Kıvılcım, B. (2020). Covid-19 (Yeni Koronavirüs) Salgının Turizm Sektörüne Muhtemel Etkileri. Uluslararası Batı Karadeniz Sosyal ve Beşeri Bilimler Dergisi, 4(1), 17-27.

Koçer, M. (2013). Televizyon İzleme Alışkanlıkları ve Motivasyonları: Kayseri Örneği, E-Journal of New World Sciences Academy, 8(2), 207-225.

Korkutata, A., Halis, M., ve Özavc1, R. (2019). Kamu Sektöründe Çalışan Personellerin Boş Zaman Tutumlarının İncelenmesi. Bilge Kağan 2 nd International Science Congress, 288.

Kurar, İ.,ve Baltacı, F. (2014). Halkın Boş Zaman Değerlendirme Alışkanlıkları: Alanya Örneği. International Journal of Science Culture and Sport (IntJSCS), 2(Special Issue 2), 39-52.

Lashuaa, B., Johnson, C. W., and Parry, D. C. (2020). Leisure in the Time of Coronavirus: A Rapid Response Special Issue. Leisure Sciences, 43 (1-2), 6-11.

Lawanson, T., Foley, L., Assah, F., Mogo, E., Mapa-Tassou, C., Ogunro, T., Onifade, V. and Oni, T. (2020). The urban environment and leisure physical activity during the COVID-19 pandemic: a view from Lagos. Cities $\mathcal{E}$ Health, Special Issue: COVID-19, 1-4. DOI: 10.1080/23748834.2020.1806459.

Mansuroğlu, S. (2002). Akdeniz Üniversitesi Öğrencilerinin Serbest Zaman Özellikleri ve Dış Mekan Rekreasyon Eğilimlerinin Belirlenmesi. Akdeniz Üniversitesi Ziraat Fakültesi Dergisi, 15(2), 53-62.

Marques, L., and Giolo, G. (2020). Cultural leisure in the time of COVID-19: impressions from the Netherlands. World Leisure Journal, 62(4), 344-348.

Mishra, N. P., Das, S. S., Yadav, S., Khan, W., Afzal, M., Alarifi, A., Kenawy, E., Ansari, M. T., Hasnain, M. S. and Nayak, A. K. (2020). Global impacts of pre- and post-COVID-19 pandemic: Focus on socio-economic consequences. Sensors International, 100042. DOI: https://doi.org/10.1016/j.sintl.2020.100042. 
Mofijur, M., Fattah, I. R., Alam, M. A., Islam, A. B., Ong, H. C., Rahman, S. M., Najafi, G., Ahmed, S. F., Uddin, M. A. and Mahlia, T. (2020). Impact of COVID-19 on the social, economic, environmental and energy domains: Lessons learnt from a global pandemic. Sustainable Production and Consumption, 26, 343-59.

Mutz, M., and Gerke, M. (2020). Sport and exercise in times of self-quarantine: How Germans changed their behaviour at the beginning of the Covid-19 pandemic. International Review for the Sociology of Sport, 56(3), 305-316.

Özdemir, Ş. ve Yaman, F. (2007). Hedonik Alışverişin Cinsiyete Göre Farklılaşması Üzerine Bir Araştırma, Eskişehir Osmangazi Üniversitesi İ̈BF Dergisi, 2(2), 81-91.

Patton, M. Q. (2005). Qualitative Research. New York: John Wiley \& Sons, Ltd.

Peter, J.P. (1981). Construct Validity: A Review of Basic Issues and Marketing Practices. Journal of Marketing Research, 18(2), 133-145. doi:10.2307/3150948

Pizam, A. and T. Ellis. (1999). Customer Satisfaction and Its Measurement in Hospitality Enterprises. International Contemporary and Hospitality Management. 11(7), 326-339.

Rajkumar, R. P. (2020). COVID-19 and mental health: A review of the existing literature. Asian Journal of Psychiatry, 52, 102066. DOI: https://doi.org/10.1016/j.ajp.2020.102066.

Roberts, K. (2020). Locked down leisure in Britain. Leisure Studies, 39(5), 617-628.

Sabbağ, Ç., ve Aksoy, E. (2011). Üniversite Öğrencileri Ve Çalışanların Boş Zaman Etkinlikleri: Adıyaman Örneği. Mehmet Akif Ersoy Üniversitesi Sosyal Bilimler Enstitüsü Dergisi, 4, 10-23.

Sağar, M.E. ve Ateş, B. (2021). Üniversite öğrencilerinde bilişsel esneklik ve duygu düzenleme becerilerinin internet bağımlılığı üzerindeki yordayıcı rolü. Uşak Üniversitesi Ĕ̆gitim Araştırmaları Dergisi, 7(1), 87-102.

Son, J. S., Nimrod, G., West, S. T., Janke, M. C., Liechty, T., and Naar, J. J. (2020). Promoting Older Adults' Physical Activity and Social Well-Being during COVID-19. Leisure Sciences, 43(1-2), 287294.

Stodolska, M. (2020). \#QuarantineChallenge2k20: Leisure in the Time of the Pandemic. Leisure Sciences, 43(1-2), 232-239.

Taştan, N. (2020). Her Açıdan Rekreasyon. C. Taşkın (Dü.) içinde, Rekreasyon Paradigması. Ankara: Gazi Kitabevi.

Tütüncü, Ö. (2012). Rekreasyon ve Rekreasyon Terapisinin Yaşam Kalitesindeki Rolü. Anatolia: Turizm Araştırmaları Dergisi, 23(2), 248-252.

www.icisleri.gov.tr. https://www.icisleri.gov.tr/koronavirus-salgini-yeni-tedbirler [Erişim Tarihi: 13.12.2020].

Yang, H., and Ma, J. (2020). How an Epidemic Outbreak Impacts Happiness: Factors that Worsen (vs. Protect) Emotional Well-being during the Coronavirus Pandemic. Psychiatry Research, 289, 113045. DOI: https://doi.org/10.1016/j.psychres.2020.113045.

Yaşlığlu, M.M. (2017). Sosyal bilimlerde faktör analizi ve geçerlilik: Keşfedici ve Doğrulayıcı faktör analizlerinin kullanılması. İstanbul Üniversitesi Isşletme Fakültesi Dergisi, 46, 74-85. 